\title{
CARACTERIZACIÓN DE DIEZ VARIEDADES DE OXALIS TUBEROSA MOLINA (OCA) Y ALTERNATIVAS DE INDUSTRIALIZACIÓN
}

\author{
Elizabeth Miriam Torres Santa Cruz y José Mario Torrico Aguilar
}

\section{RESUME}

El presente artículo muestra los resultados del análisis fisicoquímico de diez variedades de oca y los de un estudio de factibilidad para la producción de harina. El análisis de almidón, glucosa, sacarosa, fructosa, humedad, proteína, densidad, curvas de secado y factor de compresibilidad, demuestra que la variedad Titicoma presenta la más alta concentración de proteína, de 6,51\% en base seca y el menor tiempo de secado; Kellu Kamusa es la más rica en sacarosa, glucosa y fructosa, con $2,52 \%$ en tubérculo fresco. Harina y hojuelas de Kellu Kayara contienen una concentración en almidón de $84,86 \%$ en base seca y la variedad Yurac en fresco presenta el menor contenido de humedad.

El estudio de factibilidad técnica, financiera y económica para la producción anual de $1000 \mathrm{TM}$ de harina de oca Yurac con $9.5 \%$ de humedad, demuestra que el proyecto genera utilidades y desarrollo económico en las zonas productoras por su efecto multiplicador, mostrando una TIR económica de 21,5\%.

Palabras Clave: Tubérculos Andinos, Biodiversidad, Caracterización, Industrialización. 